\title{
Sykursýki af tegund 1, meðganga og árangur blóðsykurstjórnunar
}

Sigríður Sunna Gunnarsdóttir læknanemi, Arna Guðmundsdóttir² læknir, Hildur Harðardóttir ${ }^{1,3}$ læknir, Reynir Tómas Geirsson,3 læknir

\section{ÁGRIP}

Inngangur: Sykursýki af tegund 1 (SST1) hefur víðtæk áhrif á verðandi móður og ófætt barn hennar, en með góðri blóðsykurstjórnun má lágmarka fylgikvilla beggja. Markmið rannsóknarinnar var mat á útkomu meðgöngu hjá konum með SST1 á Íslandi með hliðsjón af blóðsykurstjórnun.

Efniviður og aðferðir: Afturskyggn rannsókn á meðgöngum kvenna með SST1 á árunum 1999-2010. Upplýsingar fengust úr mæðra- og fæðingarskrám um alvarleika sjúkdómsins, gildi sykurtengds blóðrauða (hemóglóbín A1c) fyrir og á meðgöngu, fæðingarmáta og fylgikvilla.

Niðurstöður: Á tímabilinu voru 93 međgöngur hjá 68 konum (47\% frumbyrjur). Meðalaldur var 29 ár og meðaltími frá greiningu sykursýki var 16 ár (miðgildi 19, bil <1-35 ár). Augnbotnabreytingar voru hjá 57\%, langvinnur háprýstingur og skjaldkirtilsjúkdómar hjá $13 \%$, en nýrna- og taugaskemmdir hjá $<10 \%$. Meðal HbA1c fyrir meðgöngu var 7,8\% en lækkaði í
$7,5 \%$ á fyrsta og 6,3\% á priðja meðgöngupriðjungi. Konur <25 ára höfðu verri blóðsykurstjórnun á fyrsta priðjungi en 25-35 ára $(p<0,04)$ og $>35$ ára konur $(p=0,02)$. Fæđing var framkölluð hjá $40 \%$ og $65 \%$ fæddu með keisaraskurði. Meðal meðgöngulengd var $37^{+2}$ vikur. Tvö börn fæddust andvana. Fyrirburar voru 28\%. Meðfædd missmíð var hjá $9 \%$ nýburanna (hjartagallar algengastir). Sykursýkiheilkenni greindist hjá priðjungi nýburanna og fjórðungur fékk nýburagulu, sem tengdist verri blóðsykurstjórnun.

Ályktanir: Konur með sykursýki 1 bættu flestar blóðsykurstjórnun, sem varð góð eða viðunandi undir lok meðgöngu eins og sást af lækkandi HbA1c gildum. Keisarafæðing var mun algengari en í almennu pýði og meira var um fylgikvilla og meðfædda missmíð meðal nýburanna. Til að lágmarka fylgikvilla parf aơ bæta sykurstjórnun fyrir pungunina og halda henni góđri.
'Læknadeild Háskóla Íslands, 'Lyflækningadeild og ${ }^{3}$ Kvennadeild, Landspitali háskólasjúkrahús, Reykjavik. Reynir Tómas Geirsson reynirtg@landspitali.is

Greinin barst 6. febrúar 2013 , sampykkt til birtingar

26. júní 2013.

Engin hagsmunatengsl gefin upp.

\section{Inngangur}

Tíðni sykursýki á Íslandi fer vaxandi eins og í öðrum vestrænum löndum. Par ber mest á sykursýki af tegund 2 (SST2), en sykursýki af tegund 1 (SST1) er einnig að aukast, pó ekki sé vitað hvað veldur pví., ${ }^{1,2}$ SST1 og SST2 fyrir pungun fóru úr 0,81\% í 1,82\% á árunum 1999-2005 og pó meðgöngusykursýki sé algengasta sykurefnaskiptatruflunin á meðgöngu, er fyrirverandi sykursýki nú um $21 \%$ allrar sykursýki á meðgöngu en var áður $10 \%{ }^{3}$

SST1 getur haft víðtæk áhrif á heilsu verðandi móður og ófædda barnsins. Pungaðar konur með fyrirverandi sykursýki eru oftar með háprýsting og fá frekar meðgöngueitrun. Ef æðasjúkdómur er til staðar er konan líklegri til að eignast fyrirbura, barn með vaxtarskerðingu eða verða fyrir burðarmálsdauða. ${ }^{4,5}$ Meðgangan getur haft áhrif á framvindu fylgikvilla sykursýkinnar. Við slæma sykurstjórnun aukast líkur á æðakvillum, svo sem í augnbotnum, og hjá um 5\% kvennanna sést versnandi nýrnastarfsemi á vaxandi prótínmigu, sem hefur forspárgildi varðandi vaxtarskerðingu fósturs og meðgöngueitrun. ${ }^{6-8}$ Á meðgöngu eykst insúlínmótstaða í vefjum sem leiðir til pess að aukið insúlín parf pegar líður á meðgönguna. Petta krefst nákvæms eftirlits alla meðgönguna og hækkandi insúlínskammta. ${ }^{9}$ Mæla parf blóðsykur 6-8 sinnum á dag, fyrir og eftir máltíðir og fyrir svefn og halda honum sem næst eðlilegum mörkum ${ }^{10}$ til að að halda langtímablóðsykri (HbA1c) sem næst eðlilegu gildi, sem er 4-6\%. Í klínískum leiðbeiningum alpjóðlegra sykursýkissamtaka (International Diabetes Federation) eru gildi undir 6,5\% hið almenna markmið fyrir sykursjúka og pað sama á við um konur á meðgöngu, ekki síst á fyrstu stigum pungunar. ${ }^{11,12}$

Sé sykurstjórnun ekki vel sinnt fyrir meðgöngu aukast líkur á fósturláti og meðfæddri missmíð fósturs á fyrstu vikum meðgöngu pegar líffæramyndun á sér stað, einkum hjarta- og miðtaugakerfisgöllum. ${ }^{13,14}$ Seinna eru verulegar líkur á að barnið verði of pungt miðað við meðgöngulengd ef sykurstjórnun er slæm (ofvöxtur, fæðingarpyngd $\geq 4500 \mathrm{~g}$ eða $>90$. hundraðsmark). ${ }^{4,15}$ Pessi stóru börn hafa oft einkennandi útlit, sykursýkiheilkenni nýbura, vegna ofvaxtar í vefjum sem eru insúlínnæmir. Ofvöxtur eykur svo líkur á fylgikvillum í fæðingu eins og axlaklemmu, verri framgangi fæðingar, súrefnispurrð í fæðingu og fósturdauða. ${ }^{16,17}$ Inngrip í meðgöngu- og fæðingarferlið eru pví mun algengari en almennt gerist, einkum framkölluð fæðing og fæðing með keisaraskurði. ${ }^{14,15,18}$ Með góðri blóðsykurstjórnun má lágmarka fylgikvilla móður og barns enda pótt áhættan verði líklega aldrei alveg jafn lág og í almennu pýði. ${ }^{11,19}$ Með aukinni pekkingu á mikilvægi góðrar blóðsykurstjórnunar og vegna betra meðgöngueftirlits hefur tíðni fósturdauða á seinni hluta meðgöngu lækkað mikið, auk pess sem meðgöngu lýkur oftast fyrir 40 vikur. Konur með SST1 fara einnig oftar í sjálfkrafa sótt fyrir tímann og framköllun fæðingar er algengari en í almennu pýði. ${ }^{20}$

Markmið rannsóknarinnar var að kanna útkomu meðgöngu með samanburði við almennt pýði á árunum 1999-2010, og meta árangur blóðsykurstjórnunar og tengsla HbA1c við fylgikvilla hjá móður og barni. 
Tafla I. Barnshafandi konur með sykursýki af tegund 1 á árunum 1999-2010. Nefnari miðast við fjölda mæðra par sem gögn fundust.

\begin{tabular}{|c|c|}
\hline \multicolumn{2}{|l|}{ Aldur (ár) } \\
\hline Miðgildi (bil) & $26(17-44)$ \\
\hline \multicolumn{2}{|l|}{ Ár frá greiningu sykursýki } \\
\hline Miðgildi (bil) & $19(<1-35)$ \\
\hline \multicolumn{2}{|l|}{ Smáæðaskemmdir } \\
\hline Augnbotnabreytingar, n (\%) & $51 / 89(57,3)$ \\
\hline Nýrnaskemmdir, n (\%) & $8 / 88(9,1)$ \\
\hline Taugaskemmdir, n (\%) & $4 / 88(4,5)$ \\
\hline Langvinnur hápýstingur, n (\%) & $12 / 89(13,3)$ \\
\hline Skjaldkirtilsjúkdómar, n (\%) & $12 / 88(13,5)$ \\
\hline \multicolumn{2}{|l|}{ Líkamspyngdarstuðull $\left(\mathrm{kg} / \mathrm{m}^{2}\right)$} \\
\hline Meðaltal (sf) & $27,2(4,1)$ \\
\hline Miðgildi (bil) & $26,4(20,9-39,6)$ \\
\hline Meðal meðgöngulengd (vikur + dagar, mörk) & $37^{+2}\left(23^{+0}-41^{+6}\right)$ \\
\hline Frumbyrjur, n (\%) & $43 / 92(47)$ \\
\hline Fyrirburafæðingar, n (\%) & $26(28)$ \\
\hline
\end{tabular}

sf = staðalfrávik

\section{Efniviður og aðferðir}

Rannsóknin var afturskyggn og náði til allra meðganga kvenna með SST1 á árunum 1999-2010. Leitað var eftir ICD-10 greiningarnúmerinu O24.0 í Fæðingaskráningunni og reyndust 165 fæðingatilkynningar hafa petta númer. Skráningin var röng 171 tilviki par sem konurnar reyndust vera með sykursýki af tegund 2 eða meðgöngusykursýki, pannig að úrtakið var 94 konur með SST1 sem fæddu einbura. Ein fjölburameðganga var undanskilin (góð útkoma fyrir móður og börn). Aðrar upplýsingar fengust úr sjúkraskrám Landspítala og Sjúkrahússins á Akureyri par sem allar konurnar fæddu.

Skráður var aldur móður við fæðingu barns, fyrri barneignir hennar, tala fósturláta (ekki með í úrvinnslu vegna ófullkominnar skráningar), hversu lengi hún hafði verið með sykursýki, aldur við greiningu, fylgikvillar sykursýki, upplýsingar um blóðsykurstjórnun samkvæmt HbA1c gildum, tíðni fylgikvilla á meðgöngu og í fæðingu og grunnupplýsingar um nýburann. Нæð og pyngd móður í fyrstu mæðraskoðun var ávallt skráð fyrir 16. viku. Líkamspyngdarstuðull (body mass index, BMI) var metinn og kjörpyngd skilgreind sem $19-24,9 \mathrm{~kg} / \mathrm{m}^{2}$, ofpyngd $25-29,9 \mathrm{~kg} / \mathrm{m}^{2}$ og offita $30 \mathrm{~kg} / \mathrm{m}^{2}$ eða meira. Síðasta mæling á lokapriðjungi meðgöngu var notuð til að meta pyngdaraukningu á meðgöngu. Til að meta HbA1c breytingar var fundin síðasta mæling á sex mánuðum fyrir meðgöngu, fyrsta mæling á fyrsta priðjungi og síðasta mæling á priðja priðjungi meðgöngu.

Meðgöngulengd við fæðingu var miðuð við ómskoðun við 12 eða 20 vikur. Fyrirburafæðing var skilgreind sem fæðing eftir 22 en fyrir 37 vikur. Skráð var upphaf fæðingar (sjálfkrafa sótt, framkölluð fæðing, fæðing með valkeisaraskurði), fæðingarmáti (eðlileg fæðing, sogklukku- eða tangarfæðing, val- eða bráðakeisaraskurður), kyn barns, fæðingarpyngd og -lengd, líkamspyngdarstuðull nýbura (ponderal index), Apgar stig við fimm mínútur og fjöldi barna með Apgar $\leq 6$ við fimm mínútna aldur. Pá var athugað hvort barn var með fyrirburaandnauð (respiratory di-
Tafla II. Blóðsykurstjórnun kvenna með sykursýki af tegund 1 fyrir, á fyrsta og lokapriðjungi meðgöngu samkvæmt HbA1c-gildum. Meðaltal, staðalfrávik og miðgildi af $\mathrm{HbA1c-gildum.}$

\begin{tabular}{ccccc}
\hline & $\begin{array}{c}\text { HbA1c fyrir } \\
\text { meðgöngu }\end{array}$ & $\begin{array}{c}\text { HbA1c á 1. } \\
\text { priðjungi }\end{array}$ & $\begin{array}{c}\text { HbA1c á 3. } \\
\text { priðjungi }\end{array}$ & $\begin{array}{c}\text { Lækkun } \\
\text { HbA1c frá } \\
\text { 1. priðjungi }\end{array}$ \\
\hline $1999-2010$ & $\mathrm{n}=54$ & $\mathrm{n}=75$ & $\mathrm{n}=80$ & $\mathrm{n}=65$ \\
\hline Meðaltal \% (sf) & $7,8(1,5)$ & $7,5(1,3)$ & $6,3(0,8)$ & $1,2(1,3)$ \\
\hline Miðgildi \% (bil) & $\begin{array}{c}7,7 \\
(5,1-12,7)\end{array}$ & $7,2(4,9-12,0)$ & $\begin{array}{c}6,3 \\
(4,6-8,2)\end{array}$ & - \\
\hline
\end{tabular}

$\mathrm{n}$ = fjöldi mæðra par sem gögn fundust, sf = staðalfrávik

stress syndrome), vot lungu (transient tachypnea), loftbrjóst, blóðsýklasótt (sepsis) eða aðrar sýkingar, meðfædda missmíð, gulu, sykursýkiheilkenni nýbura og hvort pað varð fyrir axlaklemmu í fæðingu. Meðalpyngd barna í almennu pýði á árunum 1999-2010 eftir meðgöngulengd og fjöldi fyrirburafæðinga á Landspitalanum var fenginn úr Fæðingarskráningunni.

Leyfi vegna rannsóknarinnar fengust hjá Persónuvernd, Vísindasiðanefnd, Landlæknisembættinu og framkvæmdastjóra lækninga á Landspítala og Sjúkrahúsinu á Akureyri.

\section{Tölfræðiúrvinnsla}

Meðaltal með staðalfráviki, miðgildi með bili, ásamt hlutföllum, voru notuð par sem við átti. Notast var við forritin Excel ${ }^{\circledR}$ og SPSS ${ }^{\circledR}$ (19. útgáfa, Chicago, IL, USA). Flokkabreytur voru bornar saman með Fischer's prófi. Óparað t-próf var notað til að bera saman samfelldar breytur og flokkabreytur. Athugað var hvort raðbreytur væru normaldreifðar með pví að skoða gögnin með KolmogorowSmirnov prófi. Gerð voru bæði ópöruð t-próf og Mann-Whitney próf til samanburðar ef gögnin voru ekki normaldreifð. Línuleg aðhvarfsgreining var gerð til að bera saman samfelldar breytur en lógístísk aðhvarfsgreining til að bera saman við tvíkosta útkomur. Í báðum tilvikum var notuð einpátta og fjölpátta aðhvarfsgreining. Árabilin 1999-2004 og 2005-2010 voru borin saman til að meta breytingar á nokkrum rannsóknarpáttum. Tölfræðileg marktækni miðaðist við $\mathrm{p}<0,05$.

\section{Niðurstöður}

Meðgöngur voru 93 hjá 68 konum og pví fæddu árlega að meðaltali um átta konur með SST1 (meðaltal 7,8; bil 3-14). Í töflu I er hópnum lýst. Meðalaldur var 29 ár og tæpur helmingur voru frumbyrjur. Meðaltími með sykursýki var 15,5 ár. Meðalmeðgöngulengd við fæðingu var $37^{+2}$ vikur og $28 \%$ voru fyrirburafæðingar ( $n=26$, par af 10 valkeisarafæðingar og ein framkölluð fæðing). Konur í kjörpyngd voru $38 \%, 42 \%$ í ofpyngd og $21 \%$ með offitu (samtals $63 \%$

Tafla III. Samanburður á blóðsykurstjórnun mismunandi aldurshópa kvenna með sykursýki af tegund 1 á meðgöngu.

\begin{tabular}{ccc}
\hline Aldur & HbA1c á 1. priðjungi & HbA1c á 3. priðjungi \\
\hline Meðaltal \% (sf) & Meðaltal \% (sf) \\
\hline 25 ára $(\mathrm{n}=18)$ & $8,2(1,7)^{\mathrm{a}, \mathrm{b}}$ & $6,4(0,9)$ \\
\hline 25-35 ára $(\mathrm{n}=64)$ & $7,4(1,2)^{\mathrm{a}}$ & $6,3(0,7)^{\mathrm{c}}$ \\
\hline >35 ára $(\mathrm{n}=9)$ & $6,9(0,6)^{\mathrm{b}}$ & $6,1(0,8)^{\mathrm{c}}$ \\
\hline
\end{tabular}

$\mathrm{n}$ = fjöldi mæðra sem gögn fundust um, $\mathrm{sf}$ = staðalfrávik. Marktækur munur með ópöruðu t-prófi milli hópa par sem a, b og c merkir hópa sem bornir eru saman: ${ }^{a} p=0,039 ;{ }^{b} p=0,020 ;{ }^{c} p=0,020$. 
Tafla IV. Fæðingarmáti kvenna með sykursýki af tegund 1 á árunum 1999-2010 í samanburði við almennt pýði á sama tímabili.

\begin{tabular}{|c|c|c|}
\hline & $\begin{array}{c}\text { Konur með } \\
\begin{array}{c}\text { SSTI } \\
\text { n=93 } \\
\text { n } \%\end{array}\end{array}$ & $\begin{array}{c}\text { Allar fæðingar } \\
\begin{array}{c}1999-2010 \\
n=93 \\
\%\end{array}\end{array}$ \\
\hline Framkölluð fæðing & 3640 & $16^{\star}$ \\
\hline Eðlileg fæðing & 2830 & 76 \\
\hline Fæðing með sogklukku og/eða töng & 44 & 7 \\
\hline Fæðing með keisaraskurði & 6165 & 17 \\
\hline Valaðgerð & 3032 & 7 \\
\hline Bráðaaðgerð & 3133 & 10 \\
\hline
\end{tabular}

yfir kjörpyngd), en engin kvennanna var undir kjörpyngd. Ekki var marktækur munur á líkamspyngdarstuðli milli áranna 19992004 og 2005-2010 ( $p=0,36$ ). Ekki fundust heldur tengsl á milli aldurs og BMI í línulegri aðhvarfsgreiningu $(B=-0,039 ; B=-0,49$, $\mathrm{p}=0,65$ ). Konurnar pyngdust að meðaltali um $13 \mathrm{~kg}$ (staðalfrávik $5 \mathrm{~kg}$, bil 2-27 kg). Af fylgikvillum sykursýki reyndust augnbotnabreytingar algengastar, síðan langvinnur háprýstingur og skjaldkirtilsjúkdómar, nýrna- og taugaskemmdir. Um 13\% (n = 12/89) af öllum konunum voru með háprýsting fyrir pungun, rúm $5 \%$ (n = 5/88) fengu háprýsting á meðgöngu og 19\% ( $n=18 / 88)$ fengu meðgöngueitrun. Pegar skoðað var samband blóðprýstingskvilla og pyngdar reyndust 3\% kvenna í kjörpyngd vera með langvinnan háprýsting en $9 \%$ fengu meðgöngueitrun. Meðal kvenna í ofpyngd voru $16 \%$ með langvinnan háprýsting og 16\% fengu meðgöngueitrun, en samsvarandi tölur fyrir pær offeitu voru $28 \%$.

Upplýsingar um tegund insúlínmeðferðar voru aðgengilegar í 89 meðgöngum. Á árunum 1999-2004 voru flestar konurnar á mannainsúlíni, en 2005-2010 voru langflestar á insúlínhliðstæðum sem gefnar eru með einnota pennum eða insúlíndælu. Tafla II sýnir blóðsykurstjórnun fyrir og á fyrsta og priðja priðjungi meðgöngu hjá hluta kvennanna. HbA1c mæling fyrir hvert tímabil var ekki til hjá öllum konunum. Hægt var að reikna breytingu á HbA1c frá fyrsta yfir á priðja priðjung hjá 65 kvennanna og reyndist lækkun að meðaltali um 1,2 prósentustig (16\% lækkun). Pegar borin voru saman árin 1999-2004 og 2005-2010 var ekki marktækur munur á blóðsykurstjórnun fyrir pungun og á fyrsta priðjungi meðgöngu. Á priðja priðjungi var HbA1c hins vegar marktækt lægra á fyrra tímabilinu. Konur yngri en 25 ára voru með marktækt hærra HbA1c á fyrsta priðjungi, í samanburði við 25-35 ára ( $p=0,039)$ og konur yfir 35 ára aldri $(p=0,02)$ (Tafla III). Samband aldurs og blóðsykurstjórnunar var staðfest með einpátta línulegri aðhvarfsgreiningu. Niðurstöðurnar sýndu að fyrir hvert
Tafla V. Nýburakvillar hjá börnum mæðra með sykursýki af tegund 1.

\begin{tabular}{lcc}
\hline & $\mathrm{n}$ & $\%$ \\
\hline Sykursýkiheilkenni (diabetic fetopathy) & 31 & 36 \\
\hline Gula & 20 & $23^{\star}$ \\
\hline Sýkingar & 7 & 8 \\
\hline \multicolumn{1}{c}{ Blóðsýklasótt (sepsis) } & 4 & 5 \\
\hline Öndunarfærakvillar & & \\
\hline Fyrirburaandnauð (Respiratory distress syndrome) & 3 & 4 \\
\hline Vot lungu (transient tachypnea) & 5 & 6 \\
\hline Loftbrjóst & 1 & 1 \\
\hline Fósturköfnun (asphyxia) & 2 & $2^{\star *}$ \\
\hline Axlaklemma (viðbeinsbrot) & 2 & 2 \\
\hline
\end{tabular}

Upplýsingar frá Fæđingarskráningunni um almennt pýði 1999-2009: * $=5 \%,{ }^{* *}=1 \%$.

ár í aldri var HbA1c að jafnaði 0,09 prósentustigum lægra á fyrsta priðjungi meðgöngu. Á priðja priðjungi var HbA1c að jafnaði 0,04 prósentustigum lægra fyrir hvert ár í aldri. Líkamspyngdarstuðull, tímalengd frá greiningu sykursýki, augnbotnabreytingar og nýrnaskemmdir höfðu ekki áhrif á petta samband.

Fæðing var framkölluð í 40\% tilvika, 30\% fæddu án inngripa, en $4 \%$ með töng og/eða sogklukku. Fæðing var með keisaraskurði í 65\% tilvika, par af 32\% með val- og 33\% með bráðaaðgerð (Tafla IV).

Á tímabilinu fæddust tvö andvana börn eftir 22 og 24 vikna meðgöngulengd. Pví var burðarmálsdauði 21,3/1000 fædd börn, en í almennu pýði á sama tímabili 5,3/1000. Alls fæddust átta börn með meðfædda missmíð (9\%). Par af voru fimm með hjartagalla (6\%). Aðrir gallar voru opleysi vélinda, óskriðið eista og innanrás (hypospadiasis). Ekki fannst samband milli blóðsykurstjórnunar samkvæmt HbA1c gildum og meðfæddra missmíða, hvorki með ópöruðu t-prófi né aðhvarfsgreiningu fyrir tvíflokkunarbreytu. Algengustu nýburakvillarnir voru sykursýkiheilkenni og gula. Sjaldgæfari kvillar voru blóðsýklasótt, öndunarfærakvillar, fósturköfnun og viðbeinsbrot (Tafla V). Konur sem áttu börn með sykursýkiheilkenni og/eða gulu reyndust vera með marktækt hærra meðal-HbA1c á priðja priðjungi meðgöngu heldur en hinar (Tafla VI).

Tafla VII sýnir samanburð á meðalpyngd og líkamspyngdarstuðli barna mæðra með sykursýki af tegund 1 og barna í almennu pýði miðað við meðgöngulengd. Samband var á milli pyngdarbreytinga móður og pyngdar nýbura. Fyrir hvert kílógramm sem móðirin pyngdist var barnið tæplega 42g pyngra. Pyngdaraukning móður var pó ekki sterkur forspárpáttur fyrir pyngd nýbura.

\begin{tabular}{|c|c|c|c|c|c|c|c|}
\hline & \multicolumn{3}{|c|}{ Sykursýkiheilkenni } & \multicolumn{3}{|c|}{ Ekki sykursýkiheilkenni } & \multirow[t]{2}{*}{ p-gildi } \\
\hline & $\mathrm{n}$ & $\mathrm{HbA} 1 \mathrm{c} \%$ & sf & $\mathrm{n}$ & $\mathrm{HbA} 1 \mathrm{c} \%$ & sf & \\
\hline Fyrir meðgöngu & 20 & 8,2 & 1,1 & 33 & 7,6 & 1,7 & 0,148 \\
\hline Á fyrsta priðjungi & 27 & 7,7 & 1,0 & 45 & 7,5 & 1,5 & $0,389^{*}$ \\
\hline \multirow[t]{2}{*}{ Á priðja priðjungi } & 27 & 6,6 & 0,8 & 50 & 6,2 & 0,7 & 0,013 \\
\hline & & Gula & & & Ekki gula & & \\
\hline Fyrir meðgöngu & 14 & 8,0 & 1,6 & 39 & 7,7 & 1,5 & 0,581 \\
\hline Á fyrsta priðjungi & 17 & 7,5 & 1,1 & 55 & 7,6 & 1,4 & $0,706^{\star \star}$ \\
\hline Á priðja priðjungi & 15 & 6,7 & 0,7 & 62 & 6,2 & 0,8 & 0,018 \\
\hline
\end{tabular}

$\mathrm{n}$ = fjöldi mæðra sem gögn fundust um, sf = staðalfrávik. Óparað t-próf notað, en Mann-Whitney próf til staðfestingar gaf ${ }^{*} 0,074$ og ${ }^{* \star} 0,947$ 
Tafla VII. Fæðingarpyngd og pyngdarstuðull (ponderal index) nýbura kvenna með sykursýki af tegund 1 eftir meðgöngulengd i samanburði við fullburða börn i almennu pýði 1999-2009.

\begin{tabular}{lccc}
\hline Meðgöngulengd & $\begin{array}{c}\text { Pyngd }(\mathrm{g}) \\
\text { Meðaltal (bil) }\end{array}$ & $\begin{array}{c}\text { Pyngdarstuðull } \\
\text { Miðgildi (bil) }\end{array}$ & $\begin{array}{c}\text { Meðalpyngd í } \\
\text { almennu pýði }(\mathrm{g})\end{array}$ \\
\hline$<37$ vikur $(\mathrm{n}=23)$ & $3118(1740-4880)$ & $26,6(22,2-75,0)$ & - \\
\hline $37-38$ vikur $(\mathrm{n}=14)$ & $4092(2250-5560)$ & $29,1(10,4-25,5)$ & 3119 \\
\hline $38-39$ vikur $(\mathrm{n}=30)$ & $3992(2850-5070)$ & $28,4(22,8-33,4)$ & 3390 \\
\hline $39-40$ vikur $(\mathrm{n}=20)$ & $3827(1890-5050)$ & $27,7(21,4-33,8)$ & 3618 \\
\hline $40-41$ vika $(\mathrm{n}=3)$ & $3512(3450-3555)$ & $24,5(24,4-25,3)$ & 3792 \\
\hline $41-42$ vikur $(\mathrm{n}=1)$ & 3550 & 26,7 & 3949
\end{tabular}

$\mathrm{n}=$ fjöldi barna. Pyngdarstuðull, ponderal index $(\mathrm{PI})=\mathrm{kg} / \mathrm{m}^{3}$

\section{Umræða}

Pegar niðurstöðurnar eru bornar saman við aðrar rannsóknir er mikilvægt að hafa í huga að hópurinn var lítill og par af leiðandi erfiðara að álykta um atriði eins og tíðni fylgikvilla og samband peirra við blóðsykurstjórnun. Hópurinn er samt pverskurður af konum á barneignaaldri með SST1 í heilu pjóðfélagi og tíðni fylgikvilla sykursýki var ápekk pví sem sést hefur á Íslandi. ${ }^{21}$ Meðalaldur var sá sami og hjá fæðandi konum almennt á árunum 1999-2010 (Hagstofa Íslands, www.hagstofa.is) og fjöldi frumbyrja aðeins lítillega hærri.

Á óvart kom hve hátt hlutfall kvennanna voru of pungar eða of feitar, pví sjúklingar með SST1 eru oftar í eðlilegum holdum en peir sem hafa SST2. Í mars 2008 var tekið úrtak 19,8\% barnshafandi kvenna í mæðravernd á höfuðborgarsvæðinu og líkamspyngdarstuðull peirra reiknaður (óbirtar niðurstöður; Jóna Dóra Kristinsdóttir, ljósmóðir, tilgreint með leyfi). Meðaltalið var $25,0 \mathrm{~kg} / \mathrm{m}^{2}$, samanborið við $27,2 \mathrm{~kg} / \mathrm{m}^{2}$ í SST1 rannsóknarhópnum. Í úrtakinu frá 2008 voru $44 \%$ í of pyngd eða með offitu, en í pessari rannsókn var sama hlutfall 62\%. Konur með SST1 virðast pví vera pungar miðað við aðrar konur, sem er áhyggjuefni pví par með aukast líkur á fleiri heilsufarsvandamálum, einkum háprýstingi og tengdum fylgikvillum í og utan meðgöngu. Priðjungur kvennanna pyngdist of mikið, en hæfileg pyngdaraukning á meðgöngu fyrir konur í kjörpyngd er 12-15 kg. ${ }^{22,23}$ Fyrri íslensk rannsókn sýndi tengsl vaxandi pyngdar mæðra við blóðprýstingstengda fylgikvilla meðgöngu. ${ }^{24}$ Eins og í öðrum rannsóknum fannst samband milli pyngdaraukningar móður og meiri pyngdar barnsins. ${ }^{24,25}$

Fyrirverandi háprýstingur sást hjá áttundu hverri pessara ungu kvenna, líklegast vegna undirliggjandi æðasjúkdóms samfara sykursýkinni eða ofpyngd/offitu. Petta eykur hættu á meðgöngueitrun ${ }^{8}$, sem hluti kvennanna fékk í ofanálag eins og viðbúið var ${ }^{24}$, einkum hjá peim sem voru pyngri. Konur í ofpyngd voru mun líklegri til að vera með langvinnan háprýsting. Tíðnin meðal peirra sem voru í ofpyngd var fimmföld og níföld hjá peim offeitu miðað við pær sem voru í kjörpyngd. Hið sama sást varðandi meðgöngueitrun par sem tíðnin meðal kvenna í ofpyngd var nær tvöföld og preföld hjá peim offeitu, miðað við konur sem voru í kjörpyngd. Sömu tilhneigingu hefur áður verið lýst î almennu íslensku pýði en hlutfallið var mun lægra en hjá konum með SST1. Meðal kvenna í ofpyngd í peirri rannsókn fengu um 3\% langvinnan háprýsting og tæp 4\% meðgöngueitrun en samsvarandi tölur fyrir pær offeitu voru $10 \%{ }^{24}$ Til mikils er að vinna fyrir verðandi mæður, sykursjúkar sem aðrar, að halda kjörpyngd.
Til að draga úr líkum á meðgöngueitrun er mælt með gjöf lágra skammta af asetýlsalicýlsýru pegar líkur eru auknar á meðgöngueitrun, sem á við um konur með sykursýki ${ }^{26}$, en hefja parf meðferðina fyrir 16 . viku meðgöngu. Offita íslensku kvennanna er líkleg skýring á tiltölulega hárri tíðni meðgöngueitrunar sem sást hjá aðeins 13\% kvenna í sambærilegri hollenskri rannsókn. ${ }^{15}$ Í Svípjóð voru 2\% SST1 kvenna með háprýsting fyrir meðgöngu og $14 \%$ fengu meðgöngueitrun, en $18 \%$ í danskri athugun. ${ }^{4,27}$

Langtímasykurstjórnun er oft metin með mælingu á sykurtengdum blóðrauða, en sú rannsókn er í eðli sínu afturskyggn og háð hröðum líffræðilegum breytingum á meðgöngu. Notagildi mælingarinnar til blóðsykurstjórnunar er pví takmarkaðra í pungun en utan hennar og yfirleitt er stuðst við daglegar blóðsykurmælingar. ${ }^{9,12}$ Í erlendum klínískum leiðbeiningum er mælt með að HbA1c sé haldið undir 6,5\% fyrir og á meðgöngu. ${ }^{12}$ Petta náðist ekki á Íslandi par sem HbA1c var að jafnaði um 20\% yfir markinu í upphafi meðgöngu, en á lokapriðjungi var meðaltalsgildið komið niður í 6,3\%. Ekki var munur á blóðsykurstjórnun á fimm ára tímabilunum, enda pótt á pví seinna væru flestar konurnar á insúlín hliðstæðum og insúlíndælum sem talin eru betri meðferðarúrræði. ${ }^{28}$ Blóðsykurstjórnun versnaði í öfugu hlutfalli við lífaldur. Konur yngri en 25 ára voru með marktækt hærra HbA1c á fyrsta priðjungi heldur en pær sem voru eldri, pó breytingar á HbA1c væru í samræmi við pað sem áður hefur verið sýnt. ${ }^{9}$ Yngri konurnar eru hugsanlega ekki eins móttækilegar fyrir erfiðri sykursýkimeðferð, meðan pær eldri gætu hafa hugað betur að sykurstjórnun í aðdraganda pungunarinnar. Í sumum nágrannlöndum virðast konur ná betri tökum á blóðsykurstjórnun fyrir pungun en hér. ${ }^{15,27}$

Inngrip í fæðingu voru mun tíðari hjá konunum með SST1 en í almennu pýði á sama tímabili. Fæðing var oftar framkölluð og eðlilegar fæðingar meira en helmingi færri en almennt. Nær 2/3 kvennanna fæddu með keisaraskurði, ýmist val- eða bráðaaðgerðum. Aukin tíðni fylgikvilla móður og fósturs/barns gæti skýrt pessa auknu inngripatíðni. Pegar barn er áætlað mjög stórt, eða yfir 4500g, er gjarnan mælt með valkeisaraskurði til að forðast fæðingarskaða. Pröskuldur fyrir inngripi er pví lægri en hjá konum án sykursýki. Í samanburði við Danmörku, Holland og Svípjó $ð^{4,15,27}$ reyndist Ísland vera með hæstu tíðni keisaraskurða, en börnin voru að meðaltali um 1000g pyngri en börn í almennu pýði á 37.-39. viku. Einungis fjórar konur fæddu eftir að 40 vikum var náð, en rúmur fjórðungur fæddi fyrirbura. Tíðni fyrirburafæðinga á Landspítalanum var 7,6\% á sama árabili (upplýsingar frá Fæðingaskráningunni).

Burðarmálsdauði var 21,3/1000 samanborið við 4-5/1000 á Íslandi á sama tímabili. Andvana börnin tvö fæddust eftir stutta meðgöngu í kjölfar mikilla erfiðleika móður við blóðsykurstjórnun. Varasamt er að draga miklar ályktanir um burðarmálsdauða út frá pessu litla pýði, en dauðsföllin minna engu að síður á auknar hættur samfara meðgöngu pegar móðirin er með SST1. Nýlegar rannsóknir hafa sýnt að tíðni burðarmálsdauða er enn mun hærri en í almennu pýði prátt fyrir bætta blóðsykurstjórnun., ${ }^{4,14,15}$

Annað vandamál tengt slæmri sykurstjórnun er aukin tíðni meðfæddra missmíða. Nýgengi hjartagalla á Íslandi var 1,7\% á árunum 1990-199929, en í pessari rannsókn var tíðni hjartagalla 6\%. Átta börn fæddust með alvarlega missmíð, en almennt er tíðnin á bilinu 2-3\%. Tengsl slæmrar blóðsykurstjórnunar á fyrsta priðj- 
ungi meðgöngu við auknar líkur á fósturgalla eru vel pekkt, pó merki um pað sæjust ekki með vissu í pessari rannsókn. Sykursýkiheilkenni og gula voru algengustu nýburakvillarnir. Rúmur priðjungur barnanna var með sykursýkiheilkenni og tæplega fjórðungur fékk gulu, en aðeins 5\% barna í almennu pýði fékk gulu á pessum árum (upplýsingar frá Fæðingaskráningunni). Nýburagulan verður vegna fjölgunar á rauðum blóðkornum sem viðbragð við súrefnisskorti og niðurbrot pess umframmagns eykur líkur á nýburagulu. ${ }^{30}$ Konurnar sem áttu barn með sykursýkiheilkenni og/eða gulu voru með marktækt verri blóðsykurstjórnun á priðja priðjungi meðgöngu. Tíðni fyrirburaandnauðar var hins vegar lág eða 3,5\% samanborið við 2,8\% í almennu pýði og tíðni fósturköfnunar var 2,2\% samanborið við 1,1\% (upplýsingar frá Fæðingaskráningunni). Samanburður á tíðni meðfæddrar missmíði á Íslandi og í Danmörku, Svípjóð og Hollandi sýndi ekki teljandi mun ${ }^{4,15,27}$, en gula var álíka algeng og í Hollandi. ${ }^{15}$

Styrkur rannsóknarinnar er að hún náði til allra kvenna með SST1 í einu landi og að söfnun gagna úr sjúkraskrám var á einni hendi sem ætti að hafa lágmarkað ósamræmi. Veikleikar fólust í takmörkunum afturskyggnrar rannsóknar og smæð pýðisins. Sjúkraskrár vantaði hjá nokkrum konum auk gagna fyrir nokkrar breytur, svo sem HbA1c fyrir meðgöngu. Insúlínmeðferð var breytt á tímabilinu. Loks var skráning í sjúkraskrár ekki einsleit og ICD-10 greiningarnúmerin gátu verið misskráð. Staðla parf betur skráningu á mælingum, meðal annars hæð og pyngd, blóð- sykurmælingum og HbA1c. Koma ætti á sérstakri skrá um konur með SST1, SST2 og meðgöngusykursýki til að tryggja áreiðanlega upplýsingasöfnun og par með umbætur í meðferð og sem besta útkomu meðgöngu fyrir móður og barn. Barneignaaldur og meðganga ætti að vera tækifæri til pess að bæta meðvitund um nauðsyn heilbrigðra lífshátta og góðrar blóðsykurstjórnunar fyrir getnað, á meðgöngu og eftir hana. Niðurstöðurnar staðfesta pekkt og víðtæk áhrif SST1 á móður og barn í íslensku pýði og sýna að pörf er á aðgerðum til að bæta blóðsykurstjórnun á öllum stigum meðgöngu, pó árangur hafi náđst í að bæta blóðsykurstjórnunina og útkoman hafi í heild verið góð. Fræða parf ungar konur með SST1 um pýðingu góðrar blóðsykurstjórnunar, meðal annars gegnum skipulagða pjónustu til pessa aldurshóps með tilliti til getnaðarvarna og barneigna. Hvetja parf pær til að skipuleggja barneignir, nota öruggar getnaðarvarnir og huga vel að heilsu sinni fram að pungun.

\section{Pakkir}

Anna Haarde, skrifstofustjóri kvenna- og barnasviðs LSH, Guðrún Garðarsdóttir, ritari Landsskráningar fæðinga, kvenna- og barnasviði LSH, Ingibjörg Richter, kvenna- og barnasviði. Hugbúnaðarlausnir og starfsfólk sjúkraskráasafns Landspítalans í Vesturhlíð fá pakkir fyrir hjálp við öflun gagna. Thor Aspelund, tölfræðingi er pökkuð aðstoð við tölfræðiúrvinnslu.

\section{Heimildir}

1. Patterson CC, Gyürüs E, Rosenbauer J, Cinek O, Neu A, Schober E, et al. Trends in childhood type 1 diabetes incidence in Europe during 1989-2008: evidence of nonuniformity over time in rates of increase. Diabetologia. 2012;55(8):2142-7.

2. Bergsveinsson J, Aspelund T, Guðnason V, Benediktsson R. Algengi sykursýki af tegund tvö á Íslandi 1967-2002. Læknablaðið. 2007;93(5):397-402.

3. Lawrence I, Contreras R, Chen W, Sacks D. Trends in the Prevalence of Preexisting Diabetes and Gestationa Diabetes Mellitus Among a Racially/Ethnically Diverse Population of Pregnant Women, 1999-2005. Diabetes care. 2008;31(5):899-904

4. Persson M, Norman M, Hanson U. Obstetric and Perinatal Outcomes in Type 1 Diabetic Pregnancies: A large, population-based study. Diabetes care. 2009;32(11):2005-9.

5. Gonzalez-Gonzalez NL, Ramirez O, Mozas J, Melchor J, Armas H, Garcia-Hernandez JA, et al. Factors influencing pregnancy outcome in women with type 2 versus type 1 diabetes mellitus. Acta Obst Gynecol Scand. 2008;87(1):43-

6. Rosenn BM, Miodovnik M. Medical complications of diabetes mellitus in pregnancy. Clin Obstet Gynecol. 2000;43(1):17-31.

7. Chew EY, Mills JL, Metzger BE, Remaley NA, JovanovicPeterson L, Knopp RH, et al. Metabolic control and progression of retinopathy. The Diabetes in Early Pregnancy Study. National Institute of Child Health and Human Development Diabetes in Early Pregnancy Study. Diabetes care. 1995;18(5):631-7

8. Landon MB. Diabetic nephropathy and pregnancy. Clin Obstet Gynecol. 2007:50(4):998-1006.

9. Garcia-Patterson A, Gich I, Amini SB, Catalano PM, de Leiva A, Corcoy R. Insulin requirements throughout pregnancy in women with type 1 diabetes mellitus: three changes of direction. Diabetologia. 2010;53(3):446-51.

10. Castorino K, Jovanovic L. Pregnancy and diabetes management: advances and controversies. Clin Chem. 2011;57(2):221-30.
11. Taylor R, Davison JM. Type 1 diabetes and pregnancy. BMJ. 2007;334(7596):742-5.

12. IDF Clinical Guidelines Task Force. Global Guideline on Pregnancy and Diabetes. Brussels: International Diabetes Federation; 2009

13. Åberg A, Westbom L, Källén B. Congenital malformations among infants whose mothers had gestational diabetes or preexisting diabetes. Early Hum Develop. 2001;61(2):8595.

14. Confidential Enquiry into Maternal and Child Health:Pregnancy in Women with Type 1 and Type 2 Diabetes in 2002-03, England, Wales and Northern Ireland. CEMACH, London. 2005.

15. Evers IM, de Valk HW Visser GH. Risk of complications of pregnancy in women with type 1 diabetes: nationwide prospective study in the Netherlands. BMJ. 2004;328(7445):915

16. Hawdon JM. Babies born after diabetes in pregnancy: what are the short- and long-term risks and how can we minimise them? Best Pract Res Clin Obstet Gynaecol. 2011;25(1):91-104.

17. Mathiesen ER, Ringholm L, Damm P. Stillbirth in diabetic pregnancies. Best Pract Res Clin Obstet Gynaecol. 2011;25(1):105-11.

18. Feig DS, Razzaq A, Sykora K, Hux JE, Anderson GM Trends in Deliveries, Prenatal Care, and Obstetrical Complications in Women With Pregestational Diabetes. Diabetes care. 2006;29(2):232-5.

19. Kinsley B. Achieving better outcomes in pregnancies complicated by type 1 and type 2 diabetes mellitus. Clin therapeut. 2007;29 Suppl D(Journal Article):S153-60.

20. ACOG Practice Bulletin. Clinical Management Guidelines for Obstetrician-Gynecologists. Number 60, March 2005. Pregestational diabetes mellitus. Obstet Gynecol. 2005;105(3):675-85

21. Kristinsson JK, Stefansson E, Jonasson F, Gislason I, Bjornsson S. Systematic screening for diabetic eye disease in insulin dependent diabetes. Acta ophthalmol. 1994;72(1):72-8.
22. Thorsdottir I, Torfadottir JE, Birgisdottir BE, Geirsson RT. Weight gain in women of normal weight before pregnancy: complications in pregnancy or delivery and birth outcome. Obstet Gynecol. 2002;99(5 Pt 1):799-806.

23. IOM. Weight gain during pregnancy: reexamining the guidelines. Washington, DC: National Academies Press; 2009

24. Elíasdóttir ÓJ, Harðardóttir H, Pórkelsson P. Áhrif pyngdar verðandi mæðra á meðgöngu, fæðingu og nýbura. Læknablaðið. 2010;96(11):691-6.

25. Nielsen GL, Dethlefsen C, Møller M, Sørensen HT. Maternal glycated haemoglobin, pre-gestational weight, pregnancy weight gain and risk of large-for-gestationalage babies: a Danish cohort study of 209 singleton Type 1 diabetic pregnancies. Diabet Med. 2007;24(4):384-7.

26. Visintin C MM, Almerie MQ, Nherera LM, James D, Walkinshaw S. Management of hypertensive disorders during pregnancy: summary of NICE guidance. BMJ; 2010.

27. Jensen DM, Damm P, Moelsted-Pedersen L, Ovesen P, Westergaard JG, Moeller M, et al. Outcomes in Type 1 Diabetic Pregnancies. Diabetes care. 2004;27(12):2819-23.

28. de Valk HW, Visser GHA. Insulin during pregnancy, labour and delivery. Best Pract Res Clin Obstet Gynaecol. 2011;25(1):65-76

29. Stephensen SS, Sigfusson G, Eiriksson H, Sverrisson JT, Torfason B, Haraldsson A, et al. Congenital cardiac malformations in Iceland from 1990 through 1999. Cardiol Young. 2004;14(4):396-401.

30. Widness JA, Susa JB, Garcia JF. Increased erythropoiesis and elevated erythropoietin in infants born to diabetic mothers and in hyperinsulinemic rhesus fetuses. Clin Invest. 1981;67(3):637-42. 


\section{ENGLISH SUMMARY}

\section{Diabetes of type 1, pregnancy and glycemic control}

Gunnarsdottir SS, Gudmundsdottir A, Hardardottir H, Geirsson RT

Introduction: Type 1 diabetes has wide-ranging effects for expectant mothers and their unborn children. Optimal blood sugar control minimizes complications for both. We assessed maternal and neonatal outcome in relation to glycemic control.

Material and methods: Retrospective evaluation of pregnancies among type 1 diabetic women in Iceland during 1999-2010, with information collected from maternity and newborn records on disease severity, $\mathrm{HbA1c}$ values before and during pregnancy, delivery mode and complications.

Results: There were 93 pregnancies among 68 women (47\% primigravid). Mean age was 29 years and mean time from diabetes diagnosis 16 years (median 19, range $<1-35$ years). Retinal changes affected $57 \%$, chronic hypertension and thyroid disease $13 \%$, kidney disease and neuropathy $<10 \%$. Mean $\mathrm{HbA1c}$ before pregnancy was $7.8 \%$ declining to $7.5 \%$ in first and $6.3 \%$ by third trimester. Women $<25$ had worse first

trimester blood sugar control compared to those 25-35 $(p<0.04)$ and $>35$ years $(p=0.02)$. Delivery was induced in $40 \%$ and the cesarean section rate was $65 \%$. Mean gestation was $37^{+2}$ weeks. There were two stillbirths. Preterm deliveries were $28 \%$. Congenital anomalies affected $9 \%$ of newborns (mostly cardiac). One-third of newborns developed diabetic fetopathy, one-quarter jaundice, both associated with worse maternal bloodsugars.

Conclusions: Most women with type 1 diabetes improved blood sugar control during pregnancy, which became good or acceptable by the last trimester by $\mathrm{HbA} 1 \mathrm{c}$ values. Cesarean section was over three times more frequent than in the general population. Neonatal complications and congenital anomalies were also more common. To minimize complications improved control of bloodsugar is needed before and throughout pregnancy.

Key words: Pregnancy, diabetes mellitus/type 1, hemoglobin A/glycosylated, congenital abnormalities, diabetes complications, pregnancy outcome, cesarean section, infant/ newborn, pre-eclampsia

Correspondence: Reynir Tómas Geirsson, reynirg@landspitali.is

Department of Obstetrics and Gynecology, Women's Clinic, Landspitali University Hospital, Hringbraut, 101 Reykjavik. 